\author{
Pierre Emmanuel Charles \\ José-Artur Paiva \\ Philippe Eggimann
}

\section{Contextual effect of selective oral decontamination/selective decontamination of the digestive tract on candidemia: just another word of caution!}

Received: 21 August 2015

Accepted: 22 August 2015

Published online: 10 September 2015

(C) Springer-Verlag Berlin Heidelberg and ESICM 2015

\section{P. E. Charles $(\bowtie)$}

Service de Réanimation Médicale, Hôpital Bocage Central, 14, Rue Gaffarel, Dijon, France

e-mail: pierre-emmanuel.charles@chu-dijon.fr

\section{J.-A. Paiva}

Department of Emergency and Intensive Care, Centro Hospitalar São João, Faculty of Medicine, University of Porto, Porto, Portugal e-mail: jarturpaiva@gmail.com

\section{P. Eggimann}

Department of Intensive Care Medicine, Centre Hospitalier Universitaire Vaudois (CHUV), Lausanne, Switzerland e-mail: philippe.eggimann@chuv.ch

Candidemia and other invasive candidiasis (IC) are increasingly encountered among hospitalized patients, especially in intensive care units (ICUs) [1]. Accordingly, given the reported high fatality rates, even when adequate or empirical antifungal therapy is used, preventing such infectious events has become of paramount importance, but may be responsible for antifungal overuse [2]. In most cases, candidemia is subsequent to yeast translocation from the digestive tract lumen to the blood flow [3]. Preserved interactions between yeasts and bacteria within the digestive tract are important for preventing microbiota imbalance and repressing the expression of virulence factors $[4,5]$. Antibiotic exposure, particularly through topical administration, results in major alterations of gut bacterial flora. These are likely to disturb such an equilibrium by promoting yeast expansion and progressive colonization as shown in mice and critically ill patients [6], in which it is closely related to the duration of antibiotic exposure [7]. Hence, different antibiotics are associated with different levels of risk for the development of IC. As an example, fluoroquinolones may be associated with a higher risk [8]. Host risk factors, such as gut failure following shock and/or total parenteral nutrition, hypoxia, immunoparalysis, and surgical injury, are also important and this accounts for the fact that, although Candida sp. colonization is a common finding in the ICU, IC remains a rare event $[2,7]$.

The gut is now considered as a main source of microbes potentially responsible for hospital-acquired infections and efforts have been made to develop infection control strategies, including the enteral administration of topical non-absorbable agents targeting pathogenic Enterobacteriaecae and, in some cases, also yeasts. The so-called selective digestive decontamination (SDD) or selective oral decontamination (SOD) remain controversial, despite convincing findings [9]. In a large multicenter study, De Smet et al. showed that SDD was likely to improve 28 -day mortality by approximately $3 \%$ in the ICU setting [10]. They further demonstrated that SOD might be as effective as SDD [11]. Interestingly, these studies were not controlled as a way to avoid any contextual effect of topical antibiotics. Indeed, upon the emergence of the SDD paradigm, some hypothesized that the SDD/SOD effect on the incidence of hospital-acquired infection could be "contextual" and not necessarily "direct". Thus, it was postulated that the SDD/SOD-related changes in the digestive microbiota of patients included in the treatment arm of such trials could alter in turn the patient flora in the control arm if hospitalized concurrently in the ICU [9]. As a result, Hurley suggested that nosocomial bacteremia and ventilator-associated pneumonia incidence could be increased in the control patients and the risk reduction attributable to SDD/SOD would 
thus be overestimated as a consequence of a perfidious contextual effect [12].

Hurley's current meta-analysis aimed at specifically evaluating the effect of SDD/SOD on the risk of IC, assuming that it has been so far neglected, despite the above-described rationale. Using the same unusual, but original design, he looked for a contextual effect, including control groups of patients from control groups of non-concurrent comparison studies assessing SDD/ SOD, as well as observational studies evaluating other methods for the prevention of IC, as a way to measure such a possible gap. The author found that the risk for IC was always greater in the control groups of SDD/SOD studies than in other cohorts, even after adjustment for potential usually-reported risk factors. He concluded that, in most of the randomized controlled trials designed as concurrent studies, the implementation of SDD/SOD was likely to significantly increase the risk for IC in both groups, occulting thereby this deleterious effect of SDD. Adding a topical antifungal to the SDD/SOD protocol provided a protective effect, as probably does systemic administration of antifungals. However, the meta-analysis strongly suggests that such a protective effect may be largely overestimated since it only counteracted the "artificial" increase of the risk for IC that resulted from SDD/SOD. This may explain why studies assessing the effect of topical antifungals alone failed to demonstrate any protective effect regarding the risk of IC, whereas those in which it was combined with antibacterial nonabsorbable drugs succeeded $[13,14]$. The results from the study by Garbino et al. assessing the impact of systemic fluconazole in critically ill patients under SDD also illustrate this issue [15]. Although the protective effect of both fungal colonization and infection was significant, gut flora alterations might have artificially increased the corresponding risk and the hypothesis of any translation to another group of patients (i.e., without SDD) should be regarded with caution.

In this context, the apparent beneficial effect of SDD/ SOD could be similar to tight glucose level control in the ICU, which has been probably overestimated given the obviously excessive values tolerated in the control group that are far from the standard of care [16]. Likewise, some authors have also argued that the substantial survival improvement in patients with the lower tidal volume reported in the well-known acute respiratory distress syndrome network study was at least in part due to the harmful effect of the ventilation settings applied in the control group, which did not reflect the practice at that time [17].

Hurley's meta-analysis should be viewed as another word of caution in the scrutiny of the real impact of SDD/ SOD. Its ecological consequences clearly deserve further study and further reasoning. Perhaps it should be used not as a global ICU strategy for all patients but in an individualized manner by selecting patients likely to benefit from the intervention and excluding those prone to be harmed by it, namely those continuously exposed to risk factors for candidemia and IC.

\section{Compliance with ethical standards}

Conflicts of interest None.

\section{References}

1. Lortholary O, Renaudat C, Sitbon K, Madec Y, Denoeud-Ndam L, Wolff M, Fontanet A, Bretagne S, Dromer F (2014) Worrisome trends in incidence and mortality of candidemia in intensive care units (Paris area, 2002-2010). Intensive Care Med 40:1303-1312

2. Eggimann P, Pittet D (2014) Candida colonization index and subsequent infection in critically ill surgical patients: 20 years later. Intensive Care Med 40:1429-1448

3. Montravers P, Dupont H, Eggimann P (2013) Intra-abdominal candidiasis: the guidelines-forgotten non-candidemic invasive candidiasis. Intensive Care Med 39:2226-2230

4. Morales DK, Hogan DA (2010) Candida albicans interactions with bacteria in the context of human health and disease. PLoS Pathog 6:e1000886
5. Fan D, Coughlin LA, Neubauer MM, Kim J, Kim MS, Zhan X, SimmsWaldrip TR, Xie Y, Hooper LV, Koh AY (2015) Activation of HIF-1alpha and LL-37 by commensal bacteria inhibits Candida albicans colonization. Nature Med 21:808-814

6. Samonis G, Maraki S, Leventakos K, Spanaki AM, Kateifidis A, Galanakis E, Tselentis Y, Falagas ME, Mantadakis E (2006) Comparative effects of ertapenem, imipenem, and meropenem on the colonization of the gastrointestinal tract of mice by Candida albicans. Med Mycol 44:233-235

7. Charles PE, Dalle F, Aube H, Doise JM, Quenot JP, Aho LS, Chavanet P, Blettery B (2005) Candida spp. colonization significance in critically ill medical patients: a prospective study. Intensive Care Med 31:393-400
8. Jensen JU, Hein L, Lundgren B, Bestle MH, Mohr T, Andersen MH, Loken J, Tousi H, Soe-Jensen P, Lauritsen AO, Strange D, Petersen JA, Thormar K, Larsen KM, Drenck NE, HelwegLarsen J, Johansen ME, Reinholdt K, Moller JK, Olesen B, Arendrup MC, Ostergaard C, Cozzi-Lepri A, Grarup J, Lundgren JD (2015) Invasive Candida infections and the harm from antibacterial drugs in critically ill patients: data from a randomized, controlled trial to determine the role of ciprofloxacin, piperacillin-tazobactam, meropenem, and cefuroxime. Crit Care Med 43:594-602

9. Kesecioglu J, Eggimann P (2015) What is new in selective digestive decontamination of the digestive tract ? Intensive Care Med (in press) 
10. de Smet AM, Kluytmans JA, Cooper BS, Mascini EM, Benus RF, van der Werf TS, van der Hoeven JG, Pickkers $\mathrm{P}$, Bogaers-Hofman D, van der Meer NJ, Bernards AT, Kuijper EJ, Joore JC, Leverstein-van Hall MA, Bindels AJ, Jansz AR, Wesselink RM, de Jongh BM, Dennesen PJ, van Asselt GJ, te Velde LF, Frenay IH, Kaasjager K, Bosch FH, van Iterson M, Thijsen SF, Kluge GH, Pauw W, de Vries JW, Kaan JA, Arends JP, Aarts LP, Sturm PD, Harinck HI, Voss A, Uijtendaal EV, Blok HE, Thieme Groen ES, Pouw ME, Kalkman CJ, Bonten MJ (2009)

Decontamination of the digestive tract and oropharynx in ICU patients. New Engl J Med 360:20-31
11. Oostdijk EA, Kesecioglu J, Schultz MJ, Visser CE, de Jonge E, van Essen EH, Bernards AT, Purmer I, Brimicombe R, Bergmans D, van Tiel F, Bosch FH, Mascini E, van Griethuysen A, Bindels A, Jansz A, van Steveninck FA, van der Zwet WC, Fijen JW, Thijsen S, de Jong R, Oudbier J, Raben A, van der Vorm E, Koeman M, Rothbarth P, Rijkeboer A, Gruteke P, Hart-Sweet H, Peerbooms P, Winsser LJ, van Elsacker-Niele AM, Demmendaal K, Brandenburg A, de Smet AM, Bonten MJ (2014) Effects of decontamination of the oropharynx and intestinal tract on antibiotic resistance in ICUs: a randomized clinical trial. JAMA 312:1429-1437

12. Hurley JC (2014) Topical antibiotics as a major contextual hazard toward bacteremia within selective digestive decontamination studies: a metaanalysis. BMC Infect Dis 14:714

13. Ho KM, Rochford SA, John G (2005) The use of topical nonabsorbable gastrointestinal antifungal prophylaxis to prevent fungal infections in critically ill immunocompetent patients: a metaanalysis. Crit Care Med 33:2383-2392
14. van Till JO, van Ruler O, Lamme B, Weber RJ, Reitsma JB, Boermeester MA (2007) Single-drug therapy or selective decontamination of the digestive tract as antifungal prophylaxis in critically ill patients: a systematic review. Crit Care 11:R126

15. Garbino J, Lew DP, Romand JA, Hugonnet S, Auckenthaler R, Pittet D (2002) Prevention of severe Candida infections in nonneutropenic, high-risk, critically ill patients: a randomized, double-blind, placebo-controlled trial in patients treated by selective digestive decontamination. Intensive Care Med 28:1708-1717

16. van den Berghe G, Wouters $P$, Weekers F, Verwaest C, Bruyninckx F, Schetz M, Vlasselaers D, Ferdinande P, Lauwers P, Bouillon R (2001) Intensive insulin therapy in critically ill patients. New Engl J Med 345:1359-1367

17. The acute respiratory distress syndrome network (2000) Ventilation with lower tidal volumes as compared with traditional tidal volumes for acute lung injury and the acute respiratory distress syndrome. N Engl J Med 342:1301-1308 